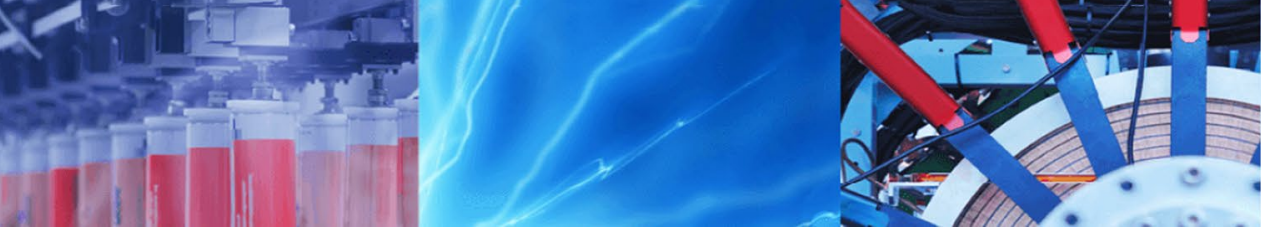

Research Article

\title{
Investigation of non-Pb all-perovskite 4-T mechanically stacked and 2-T monolithic tandem solar devices utilizing SCAPS simulation
}

\author{
Md. Tohidul Islam ${ }^{1}$ - Md. Rafsun Jani ${ }^{1}$. Sanzida Rahman ${ }^{1}$ - Kazi Md. Shorowordi ${ }^{1}$. Sadiq Shahriyar Nishat ${ }^{2}$. \\ Deidra Hodges $^{3}$. Sankha Banerjee ${ }^{4} \cdot$ Harry Efstathiadis $^{5}$. Joaquin Carbonara ${ }^{6} \cdot$ Saquib Ahmed $^{7}$ (i)
}

Received: 6 November 2020 / Accepted: 9 March 2021 / Published online: 25 March 2021

(C) The Author(s) 2021 OPEN

\begin{abstract}
SCAPS simulation was utilized to complement previously published perovskite-on-Si tandem solar devices and explore herein viable all-perovskite 4-T mechanically stacked and 2-T monolithic non-Pb tandem structures. $\mathrm{CsSn}_{0.5} \mathrm{Ge}_{0.5} \mathrm{I}_{3}(1.5 \mathrm{eV})$ was used as top cell wide bandgap absorber, while $\mathrm{CsSnl}_{3}(1.3 \mathrm{eV})$ was chosen as bottom cell low bandgap absorber. The top cell was simulated with AM 1.5G 1 Sun spectrum, and the bottom cell was simulated with the filtered spectrum from the top cell. To form a 2-T monolithic tandem device, ITO was used as the recombination layer; the current matching condition was investigated by varying the thickness of the absorber layers. For a current-matched device with a Jsc of $21.2 \mathrm{~mA} / \mathrm{cm}^{2}$, optimized thicknesses of $450 \mathrm{~nm}$ and $815 \mathrm{~nm}$ were obtained for the top and bottom absorber layers, respectively. At these thicknesses, the PCEs of the top and bottom cells were $14.08 \%$ and $9.25 \%$, respectively, and $18.32 \%$ for the final tandem configuration. A much simpler fabricated and simulated 4-T mechanically stacked tandem device, on the other hand, showcased top and bottom cell PCEs of $15.83 \%$ and $9.15 \%$, at absorber layer thicknesses of $1300 \mathrm{~nm}$ and $900 \mathrm{~nm}$, respectively, and a final overall tandem device PCE of $19.86 \%$.
\end{abstract}

Keywords Perovskites · Simulation · 2-Terminal monolithic · 4-Terminal mechanically stacked · SCAPS · Tandem device

\section{Introduction}

The global energy demand is expected to double from 15 TW (2011) to 30 TW (2050) [1-3]. Eighty-one percent of our energy demand is supplied by fossil fuel. Renewable energy, by and large, has yet to catch up to the mainstream energy market. Tandem devices of various configurations continue to be thoroughly investigated to overcome the Shockley-Queisser theoretical power conversion efficiency (PCE) limit of 31\% for the prevalent single-junction Si technology. In the last decade, III-V compound semiconductors in conjunction with Ge have been employed to achieve device PCE values of up to $39 \%$ under 1 Sun $[4,5]$. Among other high-performing devices, multi-junction solar cell structures such as GalnP/GaAs/ GalnAsP/GalnAs have demonstrated PCE values as high as $44.7 \%$ [6]. Unfortunately, these technologies require costly materials and intricate manufacturing processes, making them difficult to scale up within a commercial setting [7].

The halide perovskite technology in the past decade has provided researchers with a viable alternative to the afore-mentioned materials. Perovskite materials boast a

$\square$ Saquib Ahmed, ahmedsm@buffalostate.edu| ${ }^{1}$ Department of Materials and Metallurgical Engineering (MME), Bangladesh University of Engineering and Technology (BUET), East Campus, Dhaka 1000, Bangladesh. ${ }^{2}$ Department of Physics, Dhaka University, Dhaka 1000, Bangladesh. ${ }^{3}$ Department of Electrical and Computer Engineering, The University of Texas At El Paso, 500 W. University Avenue, El Paso, TX 79968, USA. ${ }^{4}$ Department of Mechanical Engineering, CA State University - Fresno, Fresno, 2320 E. San Ramon Avenue, Fresno, CA 93740, USA. ${ }^{5}$ College of Nanoscale Science and Nanoengineering, SUNY Polytechnic Institute, 257 Fuller Road, Albany, NY 12203 , USA. ${ }^{6}$ Department of Mathematics, SUNY - Buffalo State, 1300 Elmwood Avenue, Buffalo, NY 14222, USA. ${ }^{7}$ Department of Mechanical Engineering Technology, SUNY - Buffalo State, 1300 Elmwood Avenue, Buffalo, NY 14222, USA. 
suite of critical properties including tunable bandgaps, excellent absorption coefficients, long carrier recombination lifetimes, high electron, and hole mobilities, small electron/hole effective masses, low exciton binding energies, low cost, and solution-based fabrication process [8-10]. Perovskite-on-Si tandem solar devices have been successfully investigated to enhance PCE while bringing down the levelized cost of efficiency (LCOE) of the technology [7]. Additionally, all-perovskite tandem devices offer a route to high efficiency while maintaining the benefits of low-cost and low-temperature fabrication, together with the advantages of being lightweight and having flexible form factors [7]. These advantages are promising when juxtaposed against the constraints of the prevalent Si technology which include a need for materials quality improvement for PCE enhancement together with driving down costs [11].

Single-junction solar device physics shows that photons with energy lower than the bandgap of the absorber will not be absorbed; on the flipside, photons with higher energy will undergo thermalization losses. Multi-junction solar cells can optimize on device functionality by using several semiconductor absorbers with different bandgaps. In tandem devices, a "top cell" with a large bandgap absorber material absorbs high-energy photons, permitting lower-energy photons to pass through to be absorbed in the 'bottom cell' containing a small bandgap absorber. Thus, the higher-energy photons generate a high voltage in the top cell, while the low-energy photons generate a lower voltage in the bottom cell, raising the obtainable efficiency of the combined tandem cell over that of either cell.

Tandem solar devices are traditionally assembled either through a mechanical stacking or a monolithic arrangement. Two-terminal (2-T) monolithic tandem devices require low-temperature processing for the top cell to be directly processed on top of the bottom cell and connected by a recombination layer. Due to the 2-T configuration, only a single transparent conductive electrode is needed, lowering parasitic absorption and thus manufacturing cost. Efficient recombination contacts include highly doped $n$ - and $p$-type layers, intermediate transparent conductive oxides [TCO, such as indium-doped tin oxide (ITO)] or (ultra) thin metal layers [12]. Overall, it is challenging to fabricate high-efficiency monolithic devices due to the complexity of processing. In a mechanical stacking configuration, on the other hand, the high bandgap cell is mechanically mounted on top of the low bandgap cell. The sub-cells are fabricated independently, often by incompatible processes; mechanically stacked tandem devices are typically of a four-terminal (4-T) architecture. In the laboratory and manufacturing space, mechanical stacking is often the preferred method of tandem device fabrication due to the simplicity of implementation; it is also the simpler and more accurate method to simulate through software such as SCAPS.

Lead $(\mathrm{Pb})$ halide perovskites as photo-absorbers have showcased rapid PCE improvement in the past decade from 3.8 to $25.2 \%$ [13-15]. These Pb-based perovskite materials possess several appealing properties such as wide absorption range, large diffusion length, and highcharge-carrier mobility. While recent studies on plants suggest that the perovskite toxicity at low concentrations is solely caused by iodide ions [16], the toxicity of lead associated with the lifecycle of PSCs cannot be ignored either and poses a significant hurdle in the path toward the technology's commercialization [17-19]. Interesting future work can focus on the relative impacts of replacing iodine and lead by their non-toxic counterparts, and quantifying impacts on device performance including efficiency, stability, and degradability.

Our current work aims to introduce a tandem solar configuration that is stable, non-toxic, and cost-effective, in an effort toward responsible commercial viability. Recently, $\mathrm{CsSn}_{0.5} \mathrm{Ge}_{0.5} \mathrm{I}_{3}$ has been reported to have shown high stability under ambient conditions without encapsulation. The formation of an ultrathin $(<5 \mathrm{~nm})$ uniform native-oxide surface passivating layer on the $\mathrm{CsSn}_{0.5} \mathrm{Ge}_{0.5} \mathrm{I}_{3}$ perovskite has been critical in providing it with superior stability, even compared with the prototypical $\mathrm{MAPb}_{3}$ perovskite. It has been additionally shown that $\mathrm{CsSn}_{0.5} \mathrm{Ge}_{0.5} \mathrm{I}_{3}$ perovskite thin films can be fabricated through a facile one-step method, yielding devices with PCE up to $7.11 \%$ [20]. Lastly, $\mathrm{CsSn}_{0.5} \mathrm{Ge}_{0.5} \mathrm{I}_{3}$ solar devices have been shown to be highly stable upon continuous operation under 1-sun illumination for over $500 \mathrm{~h}$ [20]. The inorganic perovskite $\mathrm{CsSnX}_{3}(X=\mathrm{I}, \mathrm{Br}, \mathrm{Cl})$, additionally, has been considered to be a viable material to construct various optoelectronic devices, such as photodetectors, memories, solar cells, and light-emitting diodes [21]. $\mathrm{CsSnl}_{3}$ showcases the smallest bandgap in $\mathrm{CsSnX}_{3}$ perovskites family [22], together with a high thermal stability, making it an attractive material for a solar device [22]. By utilizing melt-synthesized cesium tin iodide $\left(\mathrm{CsSnl}_{3}\right)$ ingots that contains high-quality large single-crystal (SC) grains, $\mathrm{CsSnl}_{3}$ devices have shown marked improvement in bulk carrier lifetimes, doping concentration, and minority-carrier diffusion lengths [23]. Additionally, these devices exhibit low surface recombination velocity (of $2 \times 10^{3} \mathrm{cms}^{-1}$ ) [23], similar to Pb-based perovskites. The electric structure, ferroelectricity, and structural phase transitions of lead-free $\mathrm{CsSnl}_{3}$ perovskite films have been studied using first-principle-based calculations as well [24, 25]. In the study of the effect of additives on device stability, it has been summarized that additives can passivate the surface and improve the stability of $\mathrm{CsSnl}_{3}$ films, e.g., addition of $\mathrm{SnBr}_{2}$ additive in $\mathrm{CsSnl}_{3}$ films has resulted in longer 
stability [26]. The most consequential impediments for the exploitation of $\mathrm{CsSnl}_{3}$ in optoelectronic devices include the presence of a non-optically active polymorph [27] competing with the optically active polymorph at room temperature, together with the tendency of Sn to oxidize. To overcome these limitations, pulsed laser deposition (PLD) has been utilized as a unique single-source in-vacuum deposition technique for the perovskite's fabrication [27].

In previous work, the authors have explored a 2-T monolithic tandem devices utilizing perovskite-on-Si structures [28]. In this current work, we have explored a 4-T mechanically stacked and a 2-T monolithic all-perovskite tandem solar device utilizing $\mathrm{CsSn}_{0.5} \mathrm{Ge}_{0.5} \mathrm{l}_{3}$ and $\mathrm{CsSnl}_{3}$ as non-toxic absorber layers using SCAPS solar cell simulation software. For the 2-T monolithic tandem device, the strict criteria of current matching between the two sub-cells made of the two unique absorbers are explored by varying the thicknesses of individual layers. The dependency of device performance on absorber layer thickness is also explored for the 4-T mechanically stacked tandem. Optimal performance outputs for the top and bottom cells for both configurations are showcased and compared against the final tandem PCE values for each.

\section{Methodology}

In this study, the numerical simulation of perovskite-perovskite tandem solar cell is conducted using SCAPS (solar cell capacitance simulator) software, developed by the Department of Electronics and Information Systems (ELIS) of the University of Gent, Belgium [29-31]. SCAPS solves three main governing equations - transport, Poisson, and continuity equations - for the generated carriers. The Poisson equation is given by:

$\nabla^{2} V(x)=\frac{q}{\varepsilon}\left[p(x)-n(x)+N_{D}^{+}-N_{A}^{-}\right]$

where $V(x)$ is the electrostatic potential, $q$ is the charge on the electron, $\varepsilon$ is the permittivity of the absorber, $N_{A}^{-}$and $N_{D}^{+}$are acceptor and dopant densities, respectively, and $p(x)$ and $n(x)$ are position-dependent electron and hole concentrations, respectively. The carrier continuity equations are given by: $\frac{\partial p}{\partial t}=-\frac{1}{q} \nabla \cdot J_{p}-R(x)+G(x)$

where $J_{n}, J_{p}$ are electron and hole current density and $R(x)$ and $G(x)$ represent recombination and generation rates, respectively. The drift-diffusion equations for electrons and holes are given by:

$J_{n}=q n(x) \mu_{n} \frac{\mathrm{d} v(x)}{\mathrm{d} x}+q D n \frac{\mathrm{d} n(x)}{\mathrm{d} x}$

$J_{p}=q p(x) \mu_{p} \frac{\mathrm{d} v(x)}{\mathrm{d} x}+q D p \frac{\mathrm{d} p(x)}{\mathrm{d} x}$

where $\mu_{n}, \mu_{p}$ are mobility of electrons and holes and $D n, D p$ are the diffusion constant for electrons and holes, respectively.

SCAPS-1D does not support simulation of a multi-junction solar cell fully. In the mechanism of the tandem solar device, the top cell contains the higher bandgap perovskite, and the lower bandgap material is in the bottom cell. We first simulated the top cell with the standard AM 1.5G 1 Sun spectrum which was followed by the filtration of the incident AM 1.5G spectrum using the model mentioned below. The bottom cell was then simulated using the filtered spectrum from the top cell. For the 2-T monolithic tandem, a recombination layer (ITO) was introduced and the condition where the current densities of the two cells match are matched was fulfilled by varying the thicknesses of the two perovskite materials. This method is widely used in the simulation of tandem cells using SCAPS-1D [11, 32, 33].

The device fill factor (FF) is defined as follows:

$\mathrm{FF}=\frac{J_{M p}, v_{M p}}{J_{S C}, v_{O C}}$

here $J_{m p}$ and $V_{m p}$ are the current density and voltage at the maximum power point, respectively.

Device efficiency, $\eta$, normalized to input power, $P_{\text {in }}$ is defined as:

$\eta=\frac{V \mathrm{oc} \cdot \mathrm{JSC} \cdot \mathrm{FF}}{P_{\text {in }}}$.

Additional relevant equations are listed as follows:

$N_{\text {phot }}(\lambda, x)=N_{\text {photo }}(\lambda) \cdot T_{\text {front }}(\lambda) \cdot \exp (-x \cdot a(\lambda)) \times \frac{1+R_{\text {back }}(\lambda) \cdot \exp (-2(d-x) \cdot a(\lambda))}{1-R_{\text {back }}(\lambda) \cdot R_{\text {int }} \cdot \exp (-2 d \cdot a(\lambda))}$

$\frac{\partial n}{\partial t}=\frac{1}{q} \nabla \cdot J_{n}-R(x)+G(x)$

$G(\lambda, x)=a(\lambda) \cdot N_{\text {phot }}(\lambda, x)$ 


$$
\begin{aligned}
& G(x)=\int_{\lambda \min }^{\lambda \max } G(\lambda, x) \mathrm{d} \lambda \\
& \left.S(\lambda)=S_{0}(\lambda) \cdot \exp \left(\sum_{i=1}^{4}-a_{\text {mat }_{i}}(\lambda) d_{\text {mat }_{i}}\right)\right)
\end{aligned}
$$

where $N_{\text {phot }}(\lambda, x)$ is the photon flux at position $x, N_{\text {phot } 0}(\lambda)$ is the photon flux at position $x=0, T_{\text {front }}(\lambda)$ is the transmission of the front contact, $a(\lambda)$ is the absorption coefficient, $d$ represents the thickness of a layer, $R_{\text {back }}(\lambda)$ is the reflection at the back contact, $R_{\text {int }}$ is the internal reflection at the front contact, $S_{0}(\lambda)$ is the incident A.M 1.5G spectrum, $S(\lambda)$ is the filtered spectrum from the top cell, and mat $_{i}$ represents a particular material ( $i=1$ for Spiro-OMeTAD, 2 for $\mathrm{CsSn}_{0.5} \mathrm{Ge}_{0.5} \mathrm{I}_{3}, 3$ for PCBM and 4 for $\mathrm{SnO}_{2}$ ).

Figure 1 shows a plot of the filtered AM1.5G spectrum used to simulate the bottom cell in the tandem for top cell thickness.

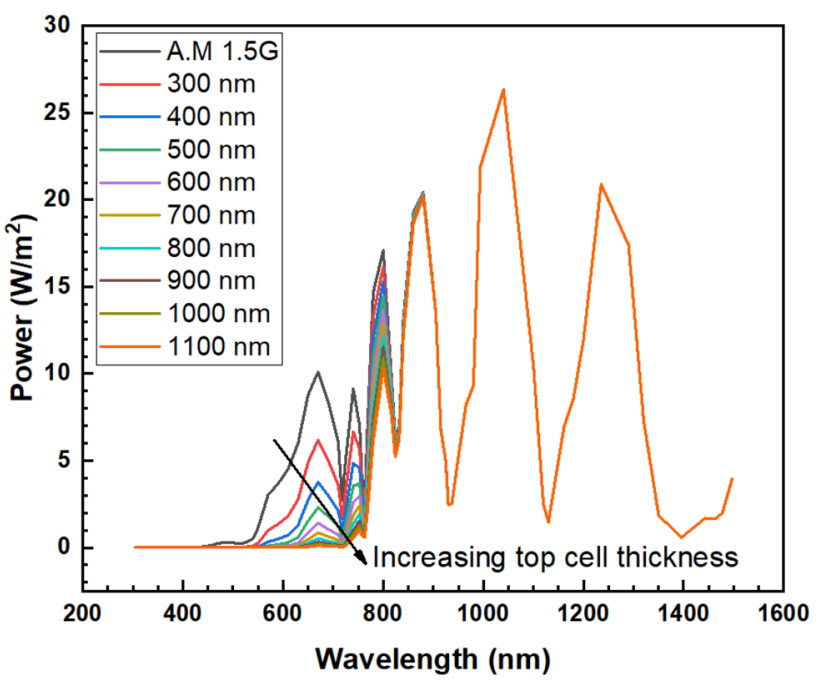

Fig. 1 Spectrum filtration according to the Eq. (11)

\section{Device structure and simulation parameters}

\subsection{Device architecture}

For a tandem solar device to function optimally, it becomes important to carefully choose the absorbers (with particular bandgaps) for the top and the bottom cells. Optimal top-band gap energies would ideally be higher (up to around $1.8 \mathrm{eV}$ ). But for such high bandgaps halide segregation issues are problematic [34, 35]. Leijtens et al. [7] have shown perovskites with bandgap in the range $1.55-1.63 \mathrm{eV}$ to have the most promising characteristics for top cells in tandem devices because of their high spectral efficiency and stability under operation conditions [36, 37]. To provide some perspective, previously published tandem (perovskite-on-perovskite) device efficiencies are listed in Table 1.

For our device, Fig. 2a, b represents the schematics of the top and bottom cells for two different configurations-2-T monolithic and 4-T mechanically stacked-of the tandem device. Figure 2a shows the sub-cells of the 2-T monolithic tandem cell connected in series utilizing ITO as the recombination layer. The 4-T mechanically stacked tandem device, as shown in Fig. 2b, comprises two independent sub-cells connected externally. Upon solar irradiation, electron/hole pairs are created in the perovskite layers; while electrons jump from the perovskite layer to the ETL, holes hop from the perovskite layer to the HTL.

The top cell of both configurations consists of SpiroOMeTAD as the HTL, PCBM as the ETL, and $\mathrm{CsSn}_{0.5} \mathrm{Ge}_{0.5} \mathrm{I}_{3}$ as the wide bandgap (1.5 eV) perovskite. The experimental feasibility of this device has been demonstrated by Chen et al. [41]. The bottom cell consists of PTAA as the HTL, $\mathrm{TiO}_{2}$ as the $\mathrm{ETL}$, Au as the metal back contact, and $\mathrm{CsSnl}_{3}$ (1.3 eV) as the low bandgap perovskite material. For the perovskite-on-perovskite tandem device, the top cell is simulated with the standard A.M 1.5G 1 Sun spectrum and the bottom cell is simulated by the filtered spectrum obtained after passing through the top cell. This filtered spectrum that strikes the bottom cell is shown in Fig. 1 (plotted as function of top cell absorber layer thickness).

Figure 3 highlights important band alignment between adjacent layers in each cell. Each material layers'

\begin{tabular}{|c|c|c|c|c|c|c|}
\hline Perovskite bottom cell (Bandgap) & Perovskite top cell (Bandgap) & Voc $(\mathrm{V})$ & $J s c\left(m A / \mathrm{cm}^{2}\right)$ & $\mathrm{FF}(\%)$ & PCE (\%) & Reference \\
\hline $\mathrm{FA}_{0.6} \mathrm{MA}_{0.4} \mathrm{Sn}_{0.6} \mathrm{~Pb}_{0.4} \mathrm{I}_{3}(1.25 \mathrm{eV})$ & $\mathrm{MAPbl}_{3}(1.55 \mathrm{eV})$ & $1.14,0.81$ & $20.1,4.8$ & 80,74 & 21 & {$[38]$} \\
\hline $\mathrm{FA}_{0.75} \mathrm{Cs}_{0.25} \mathrm{Sn}_{0.5} \mathrm{~Pb}_{0.5} \mathrm{I}_{3}(1.27 \mathrm{eV})$ & $\mathrm{FA}_{0.83} \mathrm{Cs}_{0.17} \mathrm{~Pb}\left(\mathrm{I}_{0.83} \mathrm{Br}_{0.17}\right)_{3}(1.63 \mathrm{eV})$ & $0.97,0.74$ & $20.3,7.9$ & 79,73 & 20.3 & [39] \\
\hline MASn $_{0.5} \mathrm{~Pb}_{0.5} \mathrm{I}_{3}(1.22 \mathrm{eV})$ & $\mathrm{MA}_{0.9} \mathrm{Cs}_{0.1} \mathrm{~Pb}\left(\mathrm{I}_{0.6} \mathrm{Br}_{0.4}\right)_{3}(1.82 \mathrm{eV})$ & 1.98 & 12.3 & 73 & 18.5 & {$[40]$} \\
\hline $\mathrm{FA}_{0.75} \mathrm{Cs}_{0.25} \mathrm{Sn}_{0.5} \mathrm{~Pb}_{0.5} \mathrm{I}_{3}(1.27 \mathrm{eV})$ & $\mathrm{FA}_{0.83} \mathrm{Cs}_{0.17} \mathrm{~Pb}\left(\mathrm{I}_{0.5} \mathrm{Br}_{0.5}\right)_{3}(1.85 \mathrm{eV})$ & 1.66 & 14.5 & 70 & 17 & [39] \\
\hline
\end{tabular}

Table 1 All-perovskite tandem cell efficiencies

The two values presented in the Voc, Jsc, and FF columns represent the top cell quantity (first) and the bottom cell quantity (second) 
(a)

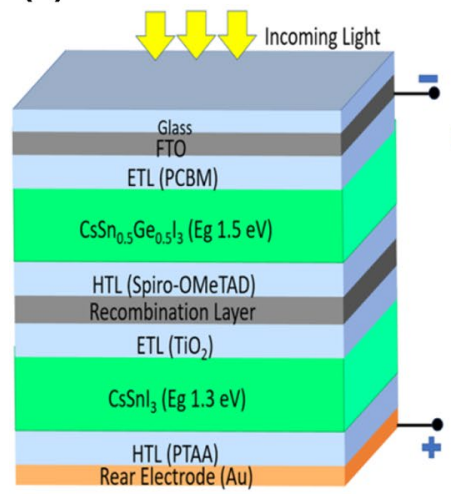

(b)

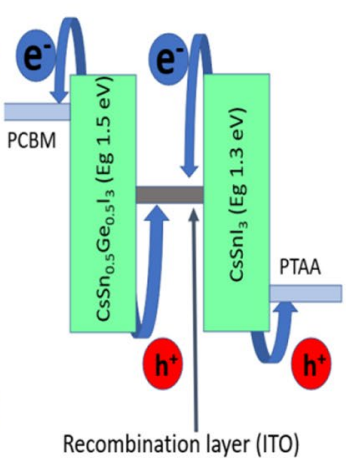

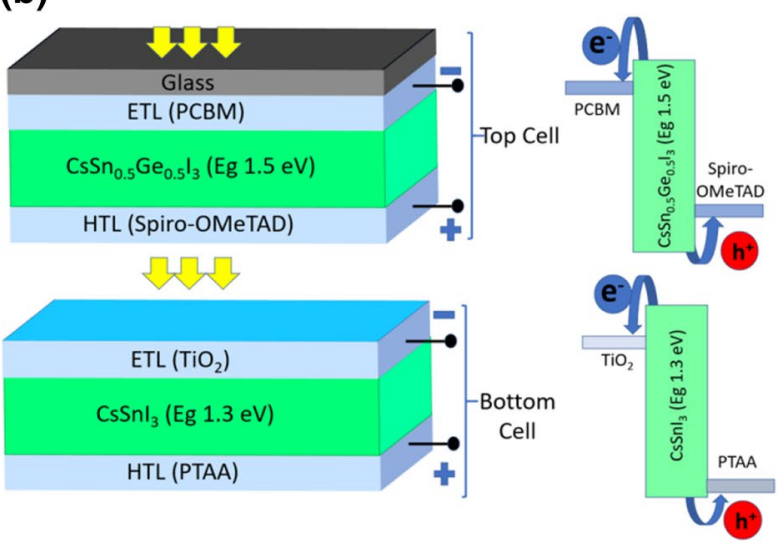

Fig. 2 Device structures modeled for simulation: a 2-T monolithic tandem and $\mathbf{b}$ 4-T mechanically stacked tandem. The pathways for electron and hole hopping from the perovskite layers to the respective ETL and HTL are also shown

conduction and valence bands are stacked up with respect to each other-the comparative positions are critical in ensuring charge transport across the device. As previously mentioned, upon solar irradiation, electron/hole pairs are created in the perovskite layer; while electrons jump from the perovskite layer to the ETL, holes hop from the perovskite layer to the HTL. A higher electron affinity (EA) of the ETL compared to the perovskite layer ensures the successful conduction of electrons at the ETL/perovskite interface, while a similar dynamic for hole conduction at the perovskite/HTL interface necessitates a higher EA of the perovskite compared to that of the HTL (listed in Table 2). With the conduction band of the HTL positioned above of that of the perovskite additionally ensures the prevention of the back flow of electrons. There is therefore an intimate dependency of the device Jsc and the Voc upon energy level disparities at both interfaces.

\subsection{Simulation parameters}

Input parameters have been carefully chosen from published literature $[31,42,43]$ and experimental works [20, 22, 44-48]. These parameters are listed in Table 2.

\section{Results and discussion}

\subsection{Validation studies: SCAPS results compared against published literature}

Table 3 provides a breakdown of the comparison between our simulated results for the top and bottom cells against experimentally published results [41, 44]. For the bottom cell, thickness values for PTAA, $\mathrm{TiO}_{2}$, and $\mathrm{CsSnl}_{3}$ are 150, 140, and $700 \mathrm{~nm}$, respectively. For the top cell, optimal thickness for Spiro-OMeTAD, PCBM, $\mathrm{SnO}_{2}$, and
Fig. 3 Energy band alignment diagram for different materials used in the tandem device

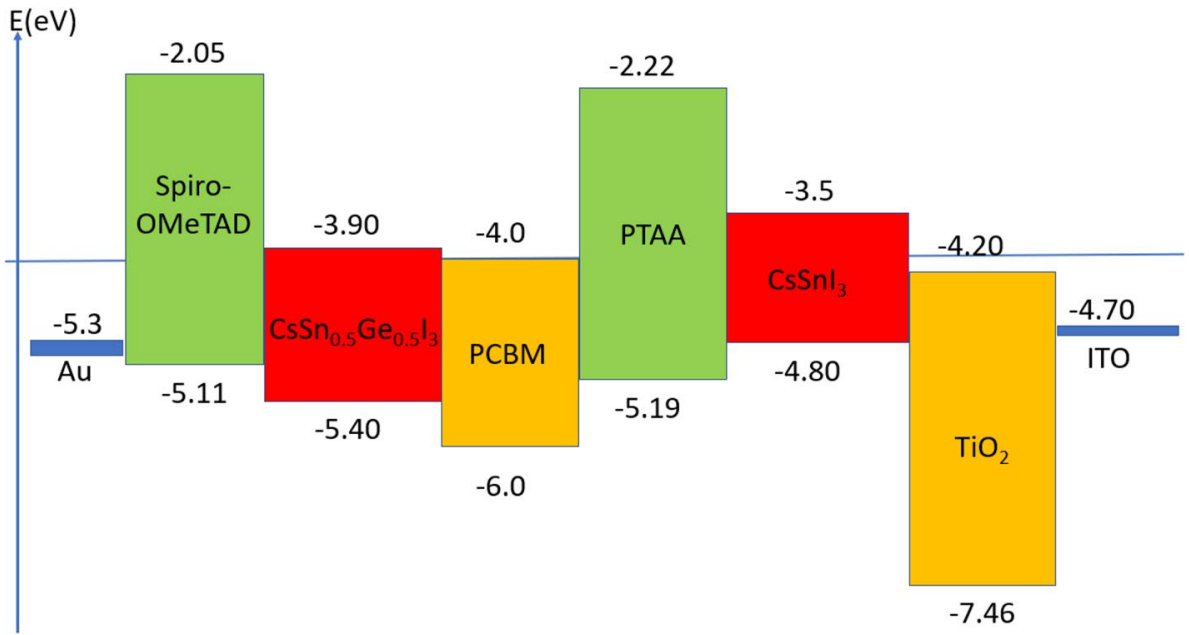

SN Applied Sciences A SPRINGER NATURE journa 
Table 2 Materials parameters used in the simulation along with interfacial defects

\begin{tabular}{|c|c|c|c|c|c|c|c|}
\hline \multirow[t]{2}{*}{ Parameter } & \multicolumn{7}{|l|}{ Materials } \\
\hline & Spiro-OMeTAD & $\mathrm{CsSn}_{0.5} \mathrm{Ge}_{0.5} \mathrm{I}_{3}$ & PCBM & ITO & PTAA & $\mathrm{CsSnl}_{3}$ & $\mathrm{TiO}_{2}$ \\
\hline Bandgap, Eg (eV) & 3.06 & 1.5 & 2 & 3.72 & 2.97 & 1.3 & 3.26 \\
\hline Electron affinity, $\mathrm{E}_{\mathrm{A}}(\mathrm{eV})$ & 2.05 & 3.9 & 4 & 3.6 & 2.22 & 3.5 & 4.2 \\
\hline Dielectric permittivity & 3 & 28 & 3.9 & 9.4 & 2.9 & 9.93 & 10 \\
\hline Conduction band density of states, $\mathrm{Nc}\left(\mathrm{cm}^{-3}\right)$ & $2.8 \times 10^{19}$ & $1.0 \times 10^{19}$ & $1.17 \times 10^{19}$ & $4.0 \times 10^{19}$ & $2.2 \times 10^{18}$ & $1.0 \times 10^{18}$ & $1.8 \times 10^{19}$ \\
\hline Valence band density of states, $\mathrm{Nv}\left(\mathrm{cm}^{-3}\right)$ & $1.0 \times 10^{19}$ & $1.0 \times 10^{19}$ & $1.12 \times 10^{18}$ & $1.0 \times 10^{18}$ & $1.8 \times 10^{19}$ & $1.0 \times 10^{18}$ & $3.5 \times 10^{19}$ \\
\hline Electron mobility (cm²/Vs) & $1.0 \times 10^{-4}$ & 974 & $2.0 \times 10^{-2}$ & 30 & $2.0 \times 10^{-3}$ & 1500 & 100 \\
\hline Hole mobility $\left(\mathrm{cm}^{2} / \mathrm{Vs}\right)$ & $2.0 \times 10^{-4}$ & 213 & $2.0 \times 10^{-2}$ & 5 & $4.0 \times 10^{-3}$ & 585 & 25 \\
\hline Donor concentration, $\left(\mathrm{cm}^{-3}\right)$ & 0 & $1.0 \times 10^{9}$ & $1.0 \times 10^{16}$ & $1.0 \times 10^{19}$ & 0 & 0 & $1.0 \times 10^{17}$ \\
\hline Acceptor concentration, $\left(\mathrm{cm}^{-3}\right)$ & $1.0 \times 10^{18}$ & $1.0 \times 10^{9}$ & 0 & 0 & $1.0 \times 10^{17}$ & $1.0 \times 10^{15}$ & 0 \\
\hline Defect density $\left(\mathrm{cm}^{-3}\right)$ & - & $1.0 \times 10^{16}$ & - & - & - & $1.0 \times 10^{18}$ & - \\
\hline \multirow[t]{2}{*}{ Parameter } & \multicolumn{7}{|l|}{ Interfaces } \\
\hline & $\begin{array}{l}\text { Spiro-OMeTAD/ } \\
\mathrm{CsSn}_{0.5} \mathrm{Ge}_{0.5} \mathrm{I}_{3}\end{array}$ & \multicolumn{2}{|c|}{$\mathrm{CsSn}_{0.5} \mathrm{Ge}_{0.5} \mathrm{I}_{3} / \mathrm{PCBM}$} & \multicolumn{2}{|c|}{ PTAA/CsSnl 3} & \multicolumn{2}{|c|}{$\mathrm{CsSnl}_{3} / \mathrm{TiO}_{2}$} \\
\hline Total defect density $\left(\mathrm{cm}^{-3}\right)$ & $1.0 \times 10^{15}$ & \multicolumn{2}{|l|}{$1.0 \times 10^{15}$} & \multicolumn{2}{|c|}{$1.0 \times 10^{15}$} & \multicolumn{2}{|c|}{$1.0 \times 10^{15}$} \\
\hline Defect type & Neutral & \multicolumn{2}{|l|}{ Neutral } & \multicolumn{2}{|l|}{ Neutral } & \multicolumn{2}{|c|}{ Neutral } \\
\hline Energetic distribution & Gaussian & \multicolumn{2}{|l|}{ Gaussian } & \multicolumn{2}{|c|}{ Gaussian } & \multicolumn{2}{|c|}{ Gaussian } \\
\hline Reference energy level & $\begin{array}{l}\text { Above valence } \\
\text { band maxima } \\
\text { (VBM) }\end{array}$ & \multicolumn{2}{|c|}{$\begin{array}{l}\text { Above valence band } \\
\text { maxima (VBM) }\end{array}$} & \multicolumn{2}{|c|}{$\begin{array}{l}\text { Above valence band } \\
\text { maxima (VBM) }\end{array}$} & \multicolumn{2}{|c|}{$\begin{array}{l}\text { Above valence } \\
\text { band maxima } \\
\text { (VBM) }\end{array}$} \\
\hline Energy level (eV) & 0.60 & \multicolumn{2}{|l|}{0.60} & \multicolumn{2}{|l|}{0.69} & \multicolumn{2}{|l|}{0.69} \\
\hline Capture cross section of electron $\left(\mathrm{cm}^{2}\right)$ & $1.0 \times 10^{-19}$ & \multicolumn{2}{|l|}{$1.0 \times 10^{-19}$} & \multicolumn{2}{|c|}{$1.0 \times 10^{-19}$} & \multicolumn{2}{|c|}{$1.0 \times 10^{-19}$} \\
\hline Capture cross section of hole $\left(\mathrm{cm}^{2}\right)$ & $1.0 \times 10^{-18}$ & \multicolumn{2}{|l|}{$1.0 \times 10^{-18}$} & \multicolumn{2}{|c|}{$1.0 \times 10^{-18}$} & \multicolumn{2}{|c|}{$1.0 \times 10^{-18}$} \\
\hline
\end{tabular}

Table 3 PV parameters of simulated top and bottom cells in comparison with the experimental PV parameters

\begin{tabular}{llcc}
\hline Cell & Performance matrix & Simulated results & $\begin{array}{l}\text { Published } \\
\text { experimental } \\
\text { results }\end{array}$ \\
\hline Bottom & $J_{\text {sc }}\left(\mathrm{mA} / \mathrm{cm}^{2}\right)$ & 25.49 & 25.71 \\
& $V_{\text {oc }}(\mathrm{V})$ & 0.38 & 0.38 \\
& $\mathrm{FF}(\%)$ & 50.8 & 49.05 \\
& PCE $(\%)$ & 4.87 & 4.81 \\
Top & $J_{\text {sc }}\left(\mathrm{mA} / \mathrm{cm}^{2}\right)$ & 15.82 & 18.61 \\
& $V_{\text {oc }}(\mathrm{V})$ & 0.68 & 0.63 \\
& $\mathrm{FF}(\%)$ & 74.14 & 60.60 \\
& $\mathrm{PCE}(\%)$ & 7.91 & 7.11 \\
\hline
\end{tabular}

$\mathrm{CsSn}_{0.5} \mathrm{Ge}_{0.5} \mathrm{I}_{3}$ is $150,140,50$, and $200 \mathrm{~nm}$, respectively. As can be seen, there is good congruence between the two sets of results.

\subsection{J-V and EQE of top and bottom cells with optimized layer thicknesses}

Simulated J-V graph for standalone top and bottom cells with optimized layer thicknesses is shown in Fig. 4a. Each cell has been simulated separately under AM 1.5G 1 Sun spectrum. The top cell shows a higher Voc compared to the bottom cell as a result of the higher bandgap of $\mathrm{CsSn}_{0.5} \mathrm{Ge}_{0.5} \mathrm{I}_{3} ; \mathrm{Jsc}$, on the other hand, is lower for the top cell compared to the bottom cell. This result is proof of the intricate dynamics and dependencies of the critical layer parameters, together with interfacial parameters, as shown in Table 2. External quantum efficiency (EQE) performances of the two cells are also shown in Fig. 4b. The better performance of the top cell in the energy range shown is consistent with its higher Jsc value as enumerated above. 
(a)

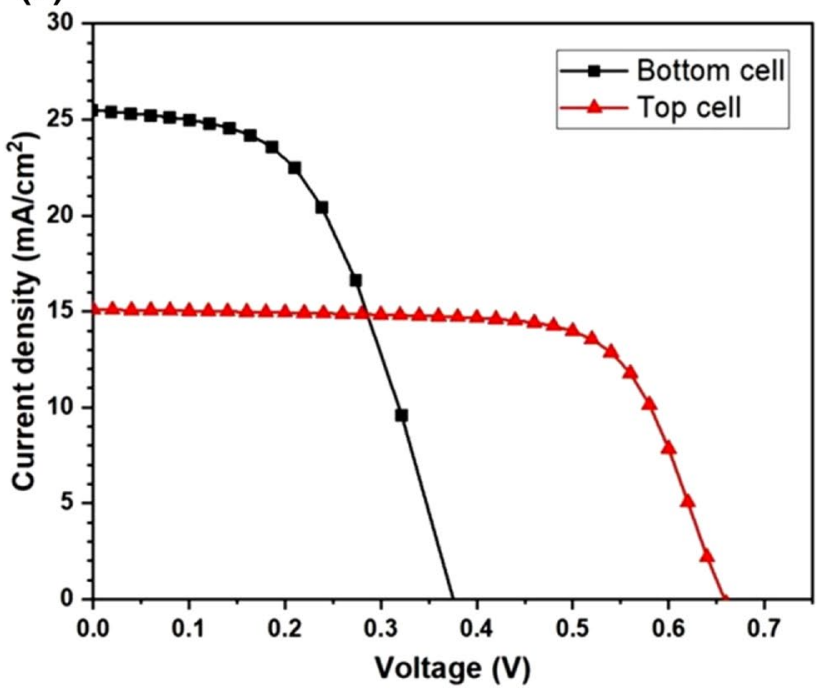

(b)

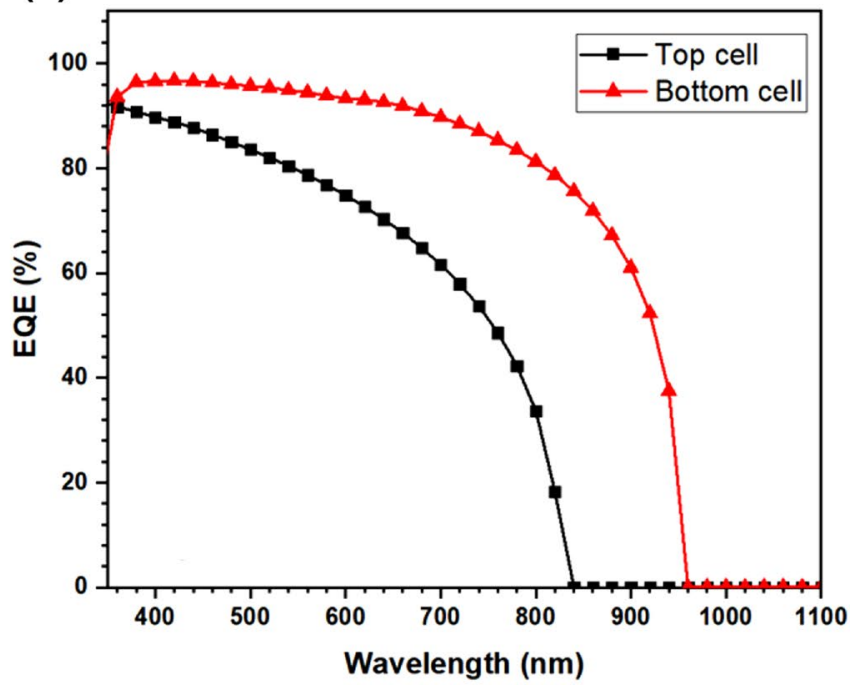

Fig. 4 Standalone top and bottom cells under standard AM 1.5G spectrum showcasing a J-V plots; b EQE plots

\subsection{2-T monolithic tandem device: impact of absorber layer thickness in top and bottom cells}

For the monolithic 2-T tandem device, both the top and the bottom cells should have the same Jsc [11]. As already mentioned, from Fig. 4, we can see the two cells have different Jsc values. To ultimately obtain the current matching condition, investigation into the impact of thicknesses variation on the top and the bottom performance has first been carried out.

The impact of absorber layer thickness on device performance is shown in Fig. 5. From the figure, we can see that for both cells, Jsc increases with increasing absorber layer thickness [49]. These improvements are due to the natural increase in the absorption of the photons due to more absorber material, leading to the generation of more electron-hole pairs and their consequent movement to the electrodes. However, current density saturates at higher absorber layer thickness values, and so the increase is more significant in the lower layer thickness range. The Jsc values of the top cell for the thicknesses $400,600,800$, 1000 , and $1200 \mathrm{~nm}$ are 20.6, 22.7, 23.9, 24.7, and $25.2 \mathrm{~mA} /$ $\mathrm{cm}^{2}$, respectively (Fig. 4a). Improvement of Jsc with the increase in the perovskite layer thickness is also true for the bottom cell (Fig. 5 b). J- $V$ curves for the $\mathrm{CsSnl}_{3}$ perovskite thickness of $400,600,800,1000$, and $1200 \mathrm{~nm}$ are 29.8, $35.6,38.7,40.4$, and $41.0 \mathrm{~mA} / \mathrm{cm}^{2}$, respectively. Lastly, it is also seen that the Voc of the top cell is less sensitive to the thickness of the absorber compared to the bottom cell.

To provide validity for the tandem structure functionality in the way that optical coupling occurs across the top and bottom cells, $J-V$ curves of the bottom cell under spectrum filtered from the top cell (with different thicknesses) are shown in Fig. $5 \mathrm{c}$. Here, the thickness of the bottom cell is kept constant at $800 \mathrm{~nm}$, while the thicknesses of the top cell have been changed. As expected, the higher the top cell thickness, the more it absorbs incoming photons, leading to lower photocurrent in the bottom cell. These trends are shown in Fig. $5 \mathrm{c}$.

\subsection{Simulation of perovskite-on-perovskite 2-T monolithic tandem solar device}

The methodology of tandem device simulation is described in Sect. 3.1. The top cell was simulated with the incident AM 1.5G 1 Sun spectrum $S_{0}(\lambda)$, and the transmitted spectrum, after the absorption by the top cell, was calculated with the help of Eq. (11).

Electrically, a 2-T tandem solar device can be considered as two diodes connected in series-this is the crucial reason why the same current must pass through both cells [11]. The cell with the minimal Jsc value limits the Jsc of the entire tandem device. Taking all the above into consideration during our simulation, the thicknesses of the two absorber layers were optimized to ensure that both have the same Jsc in the tandem device [50-53]. To this end, the top cell was simulated by varying the absorber $\left(\mathrm{CsSn}_{0.5} \mathrm{Ge}_{0.5} \mathrm{l}_{3}\right)$ layer thickness from 200 to $1500 \mathrm{~nm}$, while the thicknesses of the remaining layers were kept constant. For each given top absorber layer thickness, the unique filtered transmitted spectrum was used to irradiate the bottom cell. The optimal current matching setting showcases a value of $21.22 \mathrm{~mA} / \mathrm{cm}^{2}$ with $450 \mathrm{~nm}$ as top 

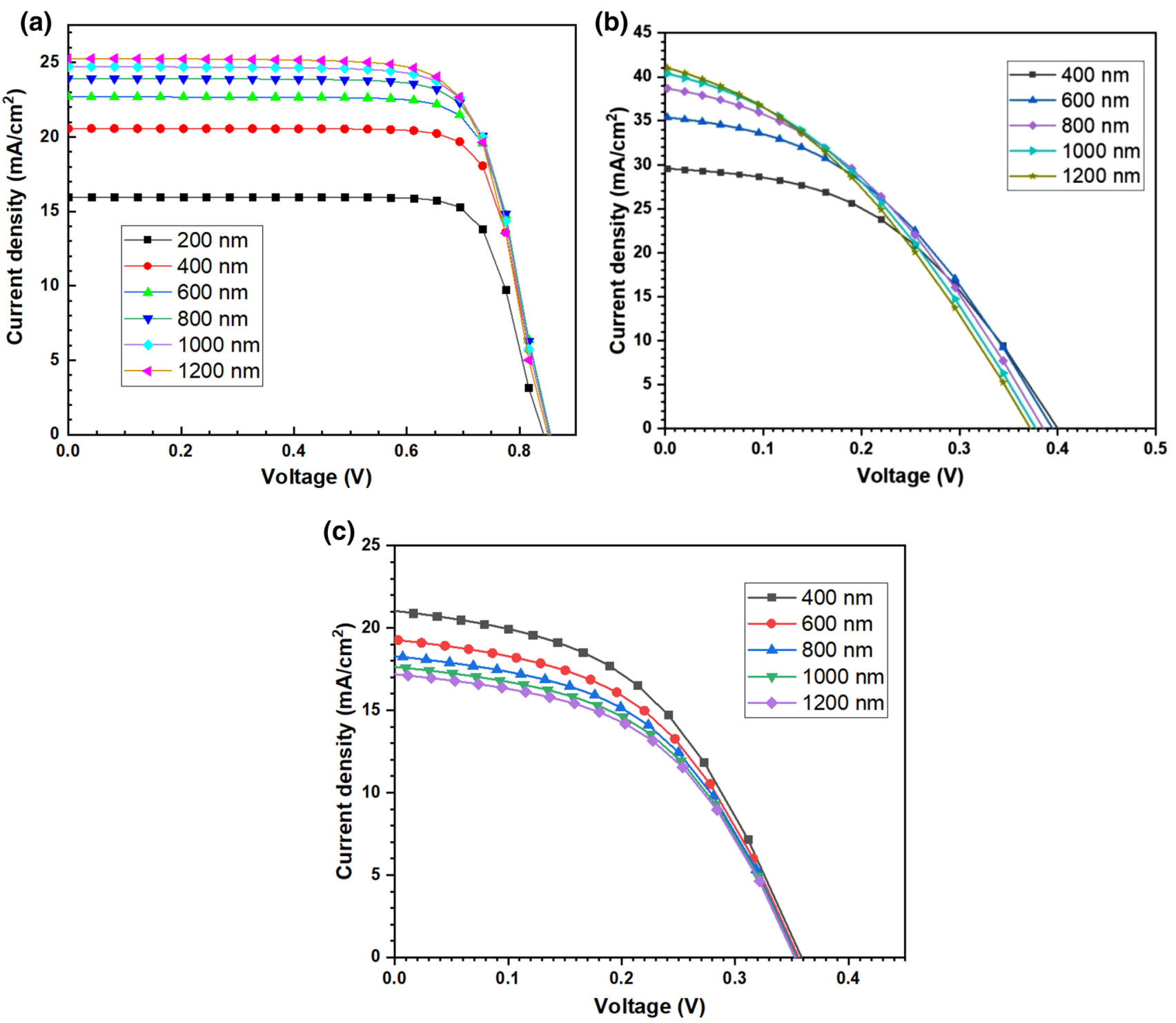

Fig. 5 Variation in the J-V curve with perovskite layer thickness in $2 \mathrm{~T}$ monolithic tandem device: a top, b bottom cell under standard AM 1.5G Sun spectrum, and $\mathrm{c}$ bottom cell with spectrum filtered by different top cell thicknesses

Table 4 PV parameters of the 2-T monolithic tandem device: top, bottom, and overall tandem device

\begin{tabular}{lllllr}
\hline Configuration & Cell & \multicolumn{2}{l}{ Optimized PV parameters } & & \\
\cline { 3 - 6 } & & Voc $(\mathrm{V})$ & JsC $\left(\mathrm{mA} / \mathrm{cm}^{2}\right)$ & FF (\%) & PCE (\%) \\
\hline 2-T monolithic tandem & Top & 0.85 & 21.222 & 77.84 & 14.08 \\
& Bottom & 0.36 & 21.219 & 62.2 & 9.25 \\
& Tandem & 1.21 & 21.22 & 71.18 & 18.32 \\
\hline
\end{tabular}

cell $\mathrm{CsSn}_{0.5} \mathrm{Ge}_{0.5} \mathrm{I}_{3}$ thickness and $815 \mathrm{~nm}$ as bottom cell $\mathrm{CsSnl}_{3}$ thickness. The PV parameter outputs utilizing the optimized layer thickness values are listed in Table 4. Figure 6 shows the $J-V$ curves of the top and bottom cells and the final tandem device. For the tandem device, each current matched $(J)$ value from the top and bottom cells gave unique voltage $(V)$ values for the corresponding cell.
These $V$ values were added together to give the voltage for the tandem device. A unique plot of $J$ versus $V$ for the tandem device could thus be plotted.

It is encouraging to see a performance output of $18.32 \%$ from the tandem device, which is higher than either of its components which showcase values of $14.08 \%$ and 9.25\% (top and bottom cells, respectively). This final PCE, 


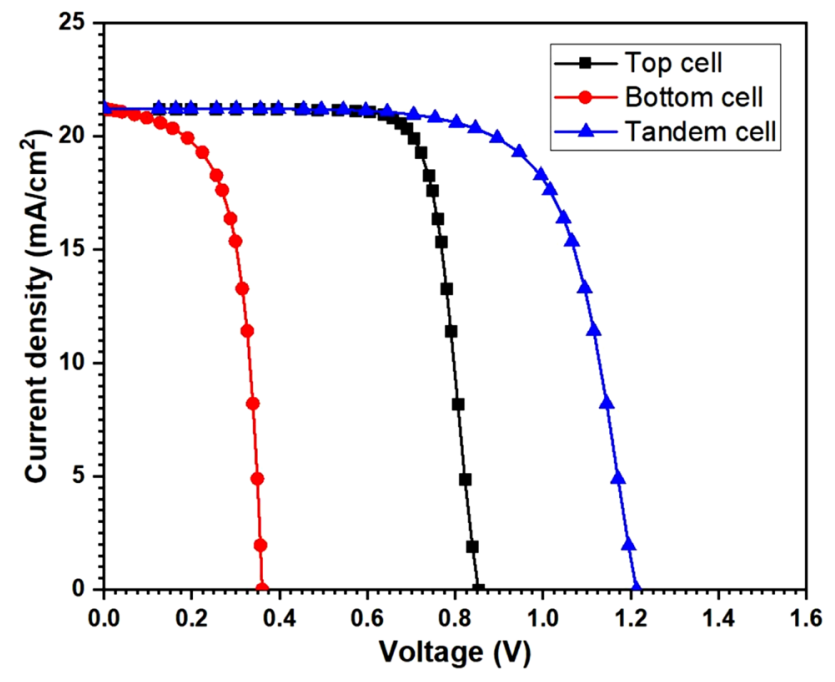

Fig. 6 J-V curve of top cell (AM 1.5G spectrum), bottom cell (filtered transmitted spectrum), and overall tandem device

while less than what $\mathrm{Pb}$-based tandem devices typically showcase-e.g., MAPbl3 perovskite on top of crystalline silicon, a two-terminal monolithic perovskite/crystalline silicon tandem device outputs a PCE of 21.2\% [54] and a 4-T all-perovskite tandem cell with MAPbI3 in the top cell outputs a PCE of $23 \%$ [55] - is competitive enough to garner interest in our device as a feasible non-toxic alternative for production at a manufacturing level.

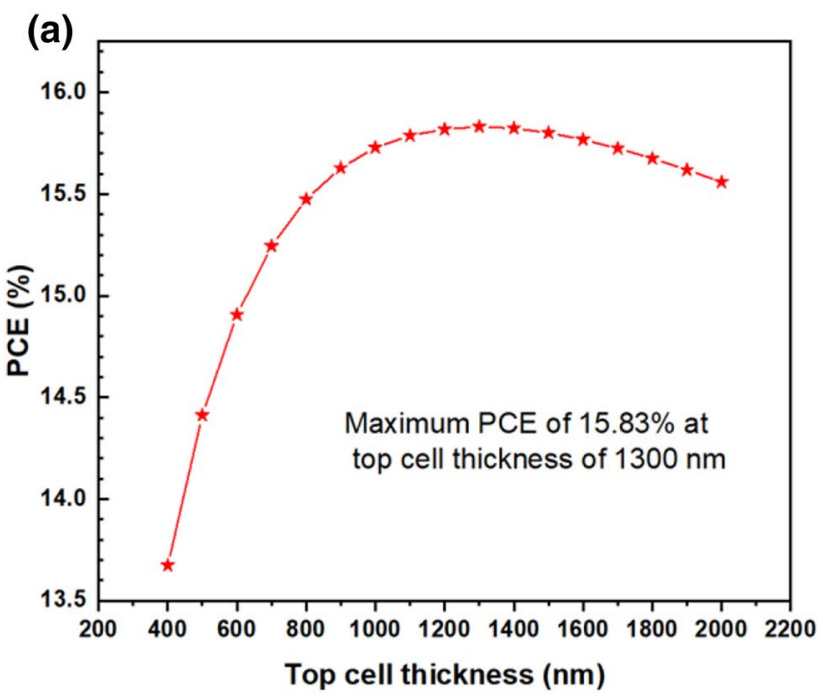

\subsection{Simulation of perovskite-on-perovskite 4-T mechanically stacked tandem solar device}

As mentioned in "Introduction," the processing of a 4-T mechanically stacked tandem device is easier compared to a 2-T monolithic tandem device because of its configuration where the two sub-cells can be fabricated separately and be contacted independently. Additionally, as shown in Sect. 4.3, the short-circuit current density, Jsc, of the $2 \mathrm{~T}$ devices is limited by the lowest Jsc containing sub-cell [56] and to match the current density in both the sub-cells the processing requires close control.

As has been showcased multiple times in previous sections, device PCE is a function of absorber layer thickness. In this case, for our 4-T mechanically stacked tandem, the effect of absorber layer thickness on PCE is shown in Fig. 7. Increasing absorber layer thickness results in an increase in device PCE due to higher numbers of generated electron-hole pairs, leading to higher photo-current. Jsc reaches a maximum and falls thereafter as the effects of recombination losses due to an increasing number of defect centers (also a function of absorber thickness) become stronger [28, 31].

For the standalone $\mathrm{CsSn}_{0.5} \mathrm{Ge}_{0.5} \mathrm{I}_{3}$ perovskite top cell under AM 1.5G 1 Sun spectrum, a maximum PCE of $15.83 \%$ is obtained at an absorber layer thickness of $1300 \mathrm{~nm}$. For the standalone $\mathrm{CsSnl}_{3}$ bottom cell, a maximum PCE of $9.5 \%$ is obtained at an absorber layer thickness of $900 \mathrm{~nm}$. According to these observations, the above-mentioned

(b)

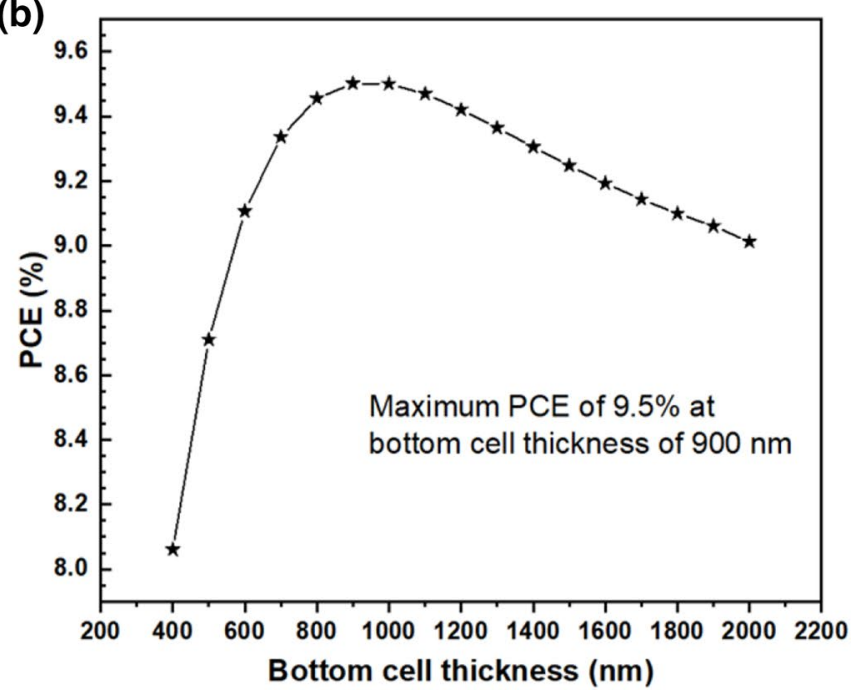

Fig. 7 The effect of absorber layer thickness on PCE 
Table 5 PV parameters of the 4-T mechanically stacked tandem device: top, bottom, and overall tandem device

\begin{tabular}{lllllr}
\hline Configuration & Cell & Voc $(\mathrm{V})$ & JsC $\left(\mathrm{mA} / \mathrm{cm}^{2}\right)$ & FF (\%) & PCE (\%) \\
\hline $\begin{array}{c}\text { 4-T mechanically } \\
\text { stacked tandem }\end{array}$ & Top & 0.85 & 25.49 & 73.36 & 15.83 \\
& Bottom & 0.35 & 18.54 & 61.12 & 9.15 \\
& Tandem & $0.85,0.35$ & $25.49,18.54$ & $73.36,61.12$ & 19.86 \\
\hline
\end{tabular}

thicknesses have been selected for the 4-T mechanically stacked tandem configuration. PV output parameters for this device are highlighted in Table 5. In addition, Fig. 8 illustrates the $J-V$ curves of the top and bottom cells. A larger photo-current is produced in the top cell compared to the bottom cell because the bottom cell was illuminated with the filtered AM $1.5 \mathrm{G}$ spectrum.

It is interesting to note that the 4-T mechanically stacked tandem device showcases a higher PCE of $19.86 \%$, compared to $18.32 \%$ in that the 2-T monolithic tandem device outputs (Table 4). We attribute this difference to losses that occur at the recombination ITO layer in the 2-T monolithic tandem configuration. Our results provide a further motivation-beyond simplicity of implementation-for researchers to probe higher performing 4-T mechanically stacked all-perovskite tandem devices and compare against their 2-T monolithic counterparts.

\section{Conclusion}

Lead-free perovskite materials, $\mathrm{CsSn}_{0.5} \mathrm{Ge}_{0.5} \mathrm{l}_{3}$ (bandgap $1.5 \mathrm{eV}$, top cell), and $\mathrm{CsSnl}_{3}$ (bandgap $1.3 \mathrm{eV}$, bottom cell), have been utilized to form both 4-T mechanically stacked

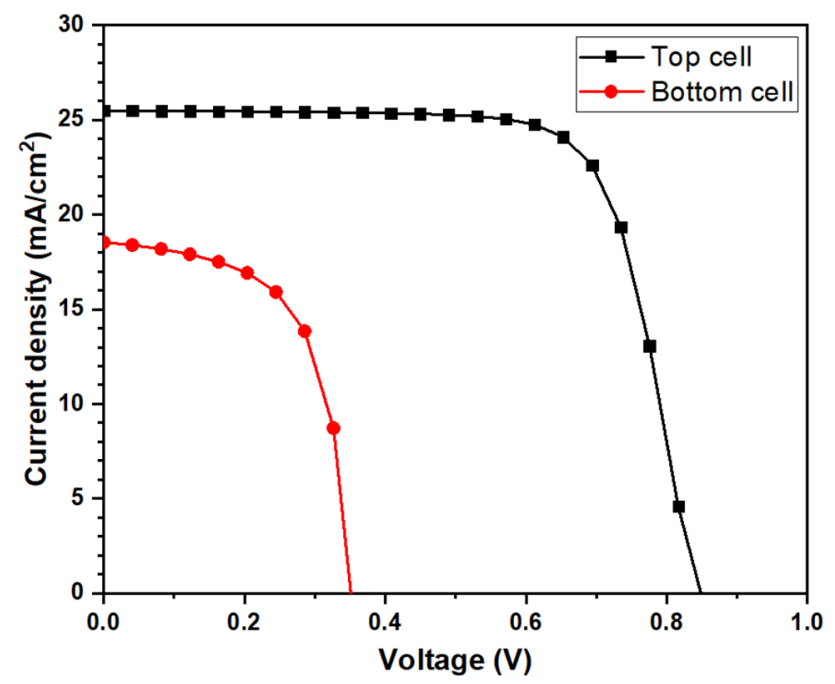

Fig. $8 \mathrm{~J}-V$ curves of the top cell (AM 1.5G spectrum), bottom cell (filtered transmitted spectrum). These two sub-cells contribute to form the final 4-T mechanically stacked tandem device PCE and 2-T monolithic perovskite-on-perovskite tandem solar devices to enhance device PCE compared to standalone devices. This research complements previously published work wherein perovskite-on-Si tandem structures were investigated. The top cell was simulated with AM 1.5G 1 Sun spectrum, and the bottom cell was simulated with the filtered spectrum from the top cell. To form a 2-T tandem device, ITO was used as the recombination layer; the current matching condition was investigated by varying the thickness of the perovskite layers. For a current-matched device with a Jsc of $21.2 \mathrm{~mA} / \mathrm{cm}^{2}$, optimized thicknesses of $450 \mathrm{~nm}$ and $815 \mathrm{~nm}$ were obtained for the top and bottom perovskite layers, respectively. At these thicknesses, the PCEs of the top and bottom cells were $14.08 \%$ and $9.25 \%$, respectively, and $18.32 \%$ for the final tandem configuration. By contrast, a much simpler 4-T mechanically stacked tandem device showcased bottom and top cell PCEs of $9.15 \%$ and $15.83 \%$, with an overall tandem device PCE of $19.86 \%$. For both the configurations, it is encouraging to see a noticeable performance improvement that the tandem device showcases over each individual sub-cell. It is equally important to note that beyond the advantage of simplicity (either through fabrication or simulation) that a 4-T mechanically stacked tandem device offers over its 2-T monolithic counterpart, it also showcases a higher PCE. Overall, our findings for both of the fully non-Pb tandem solar devices show that the final PCE values, although less than what Pb-based devices typically produce, are competitive enough to garner interest in such devices as a feasible non-toxic alternative for production at a manufacturing level.

Acknowledgements SA acknowledges the support of the Clean Energy Grant (Project \#53) from SUNY Buffalo State.

\section{Declarations}

Conflict of interest The author(s) declare that they have no competing interests.

Open Access This article is licensed under a Creative Commons Attribution 4.0 International License, which permits use, sharing, adaptation, distribution and reproduction in any medium or format, as long as you give appropriate credit to the original author(s) and the source, provide a link to the Creative Commons licence, and indicate if changes were made. The images or other third party material in this article are included in the article's Creative Commons licence, unless indicated otherwise in a credit line to the material. If material is not 
included in the article's Creative Commons licence and your intended use is not permitted by statutory regulation or exceeds the permitted use, you will need to obtain permission directly from the copyright holder. To view a copy of this licence, visit http://creativecommons. org/licenses/by/4.0/.

\section{References}

1. Sharma S, Basu S, Shetti NP, Aminabhavi TM (2020) Waste-toenergy nexus for circular economy and environmental protection: recent trends in hydrogen energy. Sci Total Environ 713:136633. https://doi.org/10.1016/j.scitotenv.2020.136633

2. Glatt MF, Yi L, Mert G, Linke BS, Aurich JC (2019) Technical product-service systems: analysis and reduction of the cumulative energy demand. J Clean Prod 206:727-740. https://doi.org/10. 1016/j.jclepro.2018.09.229

3. Seker S, Aydin N (2020) Hydrogen production facility location selection for Black Sea using entropy based TOPSIS under IVPF environment. Int J Hydrogen Energy. https://doi.org/10.1016/j. ijhydene.2019.12.183

4. Chiu PT, Law DC, Woo RL, Singer SB, Bhusari D, Hong WD, Zakaria A, Mesropian S, King RR, Karam NH (2014) 35.8\% space and 38.8\% terrestrial 5J direct bonded cells, pp 35-37

5. Hishikawa Y, Warta W, Green MA, Levi DH, Hohl J, Anita E, Baillie WYH, Dunlop ED (2017) Solar cell efficiency tables (version 50). Prog Photovolt Res Appl. https://doi.org/10.1002/pip.2909

6. Dimroth F, Grave M, Beutel P, Fiedeler U, Karcher C, Tibbits TND, Oliva E, Siefer G, Schachtner M, Wekkeli A, Bett AW, Krause R, Piccin M, Blanc N, Drazek C, Guiot E, Ghyselen B, Salvetat T, Tauzin A, Signamarcheix T, Dobrich A, Hannappel T, Schwarzburg K (2014) Wafer bonded four-junction GalnP/GaAs//GalnAsP/GalnAs concentrator solar cells with $44.7 \%$ efficiency. Prog Photovolt Res Appl. https://doi.org/10.1002/pip

7. Leijtens T, Bush KA, Prasanna R, Mcgehee MD (2018) Opportunities and challenges for tandem solar cells using metal halide perovskite semiconductors. Nat Energy. https://doi.org/10. 1038/s41560-018-0190-4

8. Im J, Lee C, Lee J, Park S, Park N (2011) 6.5\% efficient perovskite quantum-dot-sensitized solar cell. Nanoscale 2:4088-4093. https://doi.org/10.1039/c1nr10867k

9. Lee MM, Teuscher J, Miyasaka T, Murakami TN, Snaith HJ (2012) Efficient hybrid solar cells based on meso-superstructured organometal halide perovskites. Science 338:643-648

10. Senthil TS (2018) Importance of Halide Perovskites for next generation solar cells-a review. Mater Lett. https://doi.org/10. 1016/j.matlet.2018.02.089

11. Madan J, Shivani Pandey R, Sharma R (2020) Device simulation of 17.3\% efficient lead-free all-perovskite tandem solar cell. Sol Energy 197:212-221. https://doi.org/10.1016/j.solener.2020.01.006

12. Al-Ashouri A, Köhnen E, Li B, Magomedov A, Hempel H, Caprioglio P, Márquez JA, Vilches ABM, Kasparavicius E, Smith JA, Phung N, Menzel D, Grischek M, Kegelmann L, Skroblin D, Gollwitzer C, Malinauskas T, Jošt M, Matič G, Rech B, Schlatmann R, Topič M, Korte L, Abate A, Stannowski B, Neher D, Stolterfoht M, Unold T, Getautis V, Albrecht S (2020) Monolithic perovskite/silicon tandem solar cell with $>29 \%$ efficiency by enhanced hole extraction. Science 370:1300-1309. https://doi.org/10.1126/science.abd4016

13. Cui P, Wei D, Ji J, Song D, Li Y, Liu X, Huang J, Wang T, You J, Li M (2017) Highly efficient electron-selective layer free perovskite solar cells by constructing effective $\mathrm{p}-\mathrm{n}$ heterojunction. Sol RRL 1:1-7. https://doi.org/10.1002/solr.201600027

14. Kojima A, Teshima K, Shirai Y, Miyasaka T (2009) Organometal halide perovskites as visible-light sensitizers for photovoltaic cells. J Am Chem Soc 131:6050-6051
15. Elseman AM, Sharmoukh W, Sajid S, Cui P, Ji J, Dou S, Wei D, Huang H, Xi W, Chu L, Li Y, Jiang B, Li M (2018) Superior stability and efficiency over $20 \%$ perovskite solar cells achieved by a novel molecularly engineered Rutin-AgNPs/Thiophene copolymer. Adv Sci. https://doi.org/10.1002/advs.201800568

16. Hutter EM, Sangster R, Testerink C, Ehrler B, Gommers CMM (2020) Metal halide perovskite toxicity effects on plants are caused by iodide ions. pp 1-8. http://arxiv.org/abs/2012.06219

17. Pham M, Harris J, Shaffer J, Daniel A, Chowdhury S, Ali A, Banerjee $S$, Ahmed S (2019) Bismuth perovskite as a viable alternative to $\mathrm{Pb}$ perovskite solar cells: device simulations to delineate critical efficiency dynamics. J Mater Sci Mater Electron 30:94389443. https://doi.org/10.1007/s10854-019-01275-3

18. Ahmed S, Harris J, Shaffer J, Devgun M, Chowdhury S, Abdullah A, Banerjee S (2019) Simulation studies of Sn-based perovskites with Cu back-contact for non-toxic and non-corrosive devices. J Mater Res 34:2789-2795. https://doi.org/10.1557/jmr.2019.204

19. Ahmed S, Shaffer J, Harris J, Pham M, Daniel A, Chowdhury S, Ali A, Banerjee S (2019) Simulation studies of non-toxic tin-based perovskites: Critical insights into solar performance kinetics through comparison with standard lead-based devices. Superlattices Microstruct 130:20-27. https://doi.org/10.1016/j.spmi. 2019.04.017

20. Nitin P, Xiao C, Luis K, Alexander D, Ming-Gang J, Min C, Zafer H, Tianyi S, Yabing Q, Yi Z, Ronald L, Yuanyuan Z, Hector F, Domenico P (2019) Highly stable and efficient all-inorganic lead-free perovskite solar cells with native-oxide passivation. Nat Commun 10:16

21. Hong WL, Huang YC, Chang CY, Zhang ZC, Tsai HR, Chang NY, Chao YC (2016) Efficient low-temperature solution-processed lead-free perovskite infrared light-emitting diodes. Adv Mater 28:8029-8036. https://doi.org/10.1002/adma.201601024

22. Cao F, Tian W, Wang M, Wang M, Li L (2020) Stability enhancement of lead-free $\mathrm{CsSnl}_{3}$ perovskite photodetector with reductive ascorbic acid additive. InfoMat 2:577-584. https://doi.org/ 10.1002/inf2.12074

23. Wu B, Zhou Y, Xing G, Xu Q, Garces HF, Solanki A, Goh TW, Padture NP, Sum TC (2017) Long minority-carrier diffusion length and low surface-recombination velocity in inorganic lead-free $\mathrm{CsSnl}_{3}$ perovskite crystal for solar cells. Adv Funct Mater. https:// doi.org/10.1002/adfm.201604818

24. Yu C, Ren Y, Chen Z, Shum K (2013) First-principles study of structural phase transitions in $\mathrm{CsSnl}_{3}$. J Appl Phys. https://doi.org/10. 1063/1.4826068

25. Song G, Gao B, Li G, Zhang J (2017) First-principles study on the electric structure and ferroelectricity in epitaxial $\mathrm{CsSnl}_{3}$ films. RSC Adv 7:41077-41083. https://doi.org/10.1039/c7ra07735a

26. Heo JH, Kim J, Kim H, Moon SH, Im SH, Hong KH (2018) Roles of $\mathrm{SnX}_{2}(\mathrm{X}=\mathrm{F}, \mathrm{Cl}, \mathrm{Br})$ Additives in tin-based halide perovskites toward highly efficient and stable lead-free perovskite solar cells. J Phys Chem Lett 9:6024-6031. https://doi.org/10.1021/ acs.jpclett.8b02555

27. Kiyek VM, Birkhölzer YA, Smirnov $Y$, Ledinsky $M$, Remes $Z$, Momand J, Kooi BJ, Koster G, Rijnders G, Morales-Masis M (2020) Single-source, solvent-free, room temperature deposition of black $\mathrm{\gamma}$-CsSnl ${ }_{3}$ films. Adv Mater Interfaces 7:1-5. https://doi.org/ 10.1002/admi.202000162

28. Islam MT, Jani MR, Islam AF, Shorowordi KM, Chowdhury S, Nishat SS, Ahmed S (2021) Investigation of $\mathrm{CsSn}_{0.5} \mathrm{Ge}_{0.5} \mathrm{I}_{3}$-on-Si tandem solar device utilizing SCAPS simulation. IEEE Trans Electron Devices 68:618-625. https://doi.org/10.1109/TED.2020. 3045383

29. Decock K, Zabierowski P, Burgelman M (2012) Modeling metastabilities in chalcopyrite-based thin film solar cells. J Appl Phys. https://doi.org/10.1063/1.3686651 
30. Burgelman M, Nollet $P$, Degrave $S$ (2000) Modelling polycrystalline semiconductor solar cells. Thin Solid Films 361:527-532. https://doi.org/10.1016/S0040-6090(99)00825-1

31. Islam MT, Jani MR, Al Amin SM, Sami MSU, Shorowordi KM, Hossain MI, Devgun M, Chowdhury S, Banerje S, Ahmed S (2020) Numerical simulation studies of a fully inorganic $\mathrm{Cs}_{2} \mathrm{AgBiBr}_{6}$ perovskite solar device. Opt Mater 105:109957. https://doi.org/ 10.1016/j.optmat.2020.109957

32. Kim K, Gwak J, Ahn SK, Eo YJ, Park JH, Cho JS, Kang MG, Song HE, Yun JH (2017) Simulations of chalcopyrite/c-Si tandem cells using SCAPS-1D. Sol Energy 145:52-58. https://doi.org/10. 1016/j.solener.2017.01.031

33. Gupta GK, Dixit A (2018) Theoretical studies of single and tandem $\mathrm{Cu}_{2} \mathrm{ZnSn}(\mathrm{S} / \mathrm{Se})_{4}$ junction solar cells for enhanced efficiency. Opt Mater 82:11-20. https://doi.org/10.1016/j.optmat.2018.05.030

34. Hörantner MT, Leijtens T, Ziffer ME, Eperon GE, Christoforo MG, McGehee MD, Snaith HJ (2017) The potential of multijunction perovskite solar cells. ACS Energy Lett 2:2506-2513. https://doi. org/10.1021/acsenergylett.7b00647

35. Eperon GE, Hörantner MT, Snaith HJ (2017) Metal halide perovskite tandem and multiple-junction photovoltaics. Nat Rev Chem. https://doi.org/10.1038/s41570-017-0095

36. Bush KA, Palmstrom AF, Yu ZJ, Boccard M, Cheacharoen R, Mailoa JP, McMeekin DP, Hoye RLZ, Bailie CD, Leijtens T, Peters IM, Minichetti MC, Rolston N, Prasanna R, Sofia S, Harwood D, Ma W, Moghadam F, Snaith HJ, Buonassisi T, Holman ZC, Bent SF, McGehee MD (2017) 23.6\%-efficient monolithic perovskite/ silicon tandem solar cells with improved stability. Nat Energy 2:1-7. https://doi.org/10.1038/nenergy.2017.9

37. Saliba M, Matsui T, Domanski K, Seo J-Y, Ummadisingu A, Zakeeruddin SM, Correa-Baena JP, Tress WR, Abate A, Hagfeldt A (2016) In Coorporation of Rb in Cs based perovskite. Science 354:206-210

38. Zhao D, Yu Y, Wang C, Liao W, Shrestha N, Grice CR, Cimaroli AJ, Guan L, Ellingson RJ, Zhu K, Zhao X, Xiong RG, Yan Y (2017) Lowbandgap mixed tin-lead iodide perovskite absorbers with long carrier lifetimes for all-perovskite tandem solar cells. Nat Energy 2:1-7. https://doi.org/10.1038/nenergy.2017.18

39. Eperon GE, Eperon GE, Leijtens T, Bush KA, Prasanna R, Green T, Wang JT, Mcmeekin DP, Volonakis G, Milot RL, May R, Palmstrom A, Daniel J, Belisle RA, Patel JB, Parrott ES, Sutton RJ, Ma W, Conings $B$, Babayigit A, Boyen $H$, Bent $S$, Giustino F, Herz M, Johnston MB, Mcgehee MD, Snaith HJ (2016) Perovskite-perovskite tandem photovoltaics with optimized bandgaps. Science 9717:1-10

40. Rajagopal A, Yang Z, Jo SB, Braly IL, Liang PW, Hillhouse HW, Jen AKY (2017) Highly efficient perovskite-perovskite tandem solar cells reaching $80 \%$ of the theoretical limit in photovoltage. Adv Mater 29:1-10. https://doi.org/10.1002/adma.201702140

41. Chen M, Ju MG, Garces HF, Carl AD, Ono LK, Hawash Z, Zhang Y, Shen T, Qi Y, Grimm RL, Pacifici D, Zeng XC, Zhou Y, Padture NP (2019) Highly stable and efficient all-inorganic lead-free perovskite solar cells with native-oxide passivation. Nat Commun 10:1-8. https://doi.org/10.1038/s41467-018-07951-y

42. Islam T, Jani R, Al Amin SM, Shorowordi KM, Nishat SS, Kabir A, Taufique MFN, Chowdhury S, Banerjee S, Ahmed S (2020) Simulation studies to quantify the impacts of point defects: an investigation of $\mathrm{Cs}_{2} \mathrm{AgBiBr}_{6}$ perovskite solar devices utilizing $\mathrm{ZnO}$ and $\mathrm{Cu}_{2} \mathrm{O}$ as the charge transport layers. Comput Mater Sci. https:// doi.org/10.1016/j.commatsci.2020.109865

43. Jani MR, Islam MT, Al Amin SM, Us Sami MS, Shorowordi KM, Hossain MI, Chowdhury S, Nishat SS, Ahmed S (2020) Exploring solar cell performance of inorganic $\mathrm{Cs}_{2} \mathrm{TiBr}_{6}$ halide double perovskite: a numerical study. Superlattices Microstruct 146:106652. https://doi.org/10.1016/j.spmi.2020.106652
44. Bin Song T, Yokoyama T, Aramaki S, Kanatzidis MG (2017) Performance enhancement of lead-free tin-based perovskite solar cells with reducing atmosphere-assisted dispersible additive. ACS Energy Lett 2:897-903. https://doi.org/10.1021/acsenergyl ett.7b00171

45. Bak T, Nowotny MK, Sheppard LR, Nowotny J (2008) Mobility of electronic charge carriers in titanium dioxide. J Phys Chem C 112:12981-12987. https://doi.org/10.1021/jp801028j

46. Leijtens T, Ding I, Giovenzana T, Bloking JT, Mcgehee MD, Sellinger A (2012) Hole transport materials with low glass transition temperatures and high solubility for application in solid-state dye-sensitized solar cells. ACS Nano 6:1455-1462

47. Abdul Kareem T, Anu Kaliani A (2015) Fabrication and characterization of ZnSCubic: P3HT, ZnSHexa: P3HT and ZnSHexa: P3HT: PVA-Ag bulk heterojunction solar cells. J Nano-Electron Phys 7:1-6

48. Jarwal DK, Mishra AK, Kumar A, Ratan S, Singh AP, Kumar $C$, Mukherjee $B$, Jit $S$ (2020) Fabrication and TCAD simulation of $\mathrm{TiO}_{2}$ nanorods electron transport layer based perovskite solar cells. Superlattices Microstruct 140:106463. https://doi.org/10. 1016/j.spmi.2020.106463

49. Islam MT, Jani MR, Shorowordi KM, Hoque Z, Gokcek AM, Vattipally V, Nishat SS, Ahmed S (2021) Numerical simulation studies of $\mathrm{Cs}_{3} \mathrm{Bi} 2 \mathrm{I}_{\text {g }}$ perovskite solar device with optimal selection of electron and hole transport layers. Optik. https://doi.org/10. 1016/j.jileo.2021.166417

50. Ramírez Quiroz CO, Spyropoulos GD, Salvador M, Roch LM, Berlinghof M, Darío Perea J, Forberich K, Dion-Bertrand LI, Schrenker NJ, Classen A, Gasparini N, Chistiakova G, Mews M, Korte L, Rech B, Li N, Hauke F, Spiecker E, Ameri T, Albrecht S, Abellán G, León S, Unruh T, Hirsch A, Aspuru-Guzik A, Brabec CJ (2019) Interface Molecular Engineering for Laminated Monolithic Perovskite/Silicon Tandem Solar Cells with 804\% Fill Factor. Adv Funct Mater. https://doi.org/10.1002/adfm.201901476

51. Pandey R, Chaujar R (2016) Numerical simulations: toward the design of $27.6 \%$ efficient four-terminal semi-transparent perovskite/SiC passivated rear contact silicon tandem solar cell. Superlattices Microstruct. 100:656-666. https://doi.org/10. 1016/j.spmi.2016.10.033

52. Chen B, Yu Z, Liu K, Zheng X, Liu Y, Shi J, Spronk D, Rudd PN, Holman Z, Huang J (2019) Grain engineering for perovskite/silicon monolithic tandem solar cells with efficiency of $25.4 \%$. Joule 3:177-190. https://doi.org/10.1016/j.joule.2018.10.003

53. Sahli F, Werner J, Kamino BA, Bräuninger M, Monnard R, PavietSalomon B, Barraud L, Ding L, Diaz Leon JJ, Sacchetto D, Cattaneo G, Despeisse M, Boccard M, Nicolay S, Jeangros Q, Niesen B, Ballif C (2018) Fully textured monolithic perovskite/silicon tandem solar cells with $25.2 \%$ power conversion efficiency. Nat Mater 17:820-826. https://doi.org/10.1038/s41563-018-0115-4

54. Werner J, Weng $C H$, Walter $A$, Fesquet $L$, Seif JP, De Wolf $S$, Niesen B, Ballif C (2016) Efficient monolithic perovskite/silicon tandem solar cell with cell area $>1 \mathrm{~cm}^{2}$. J Phys Chem Lett 7:161-166. https://doi.org/10.1021/acs.jpclett.5b02686

55. Zhao D, Wang C, Song Z, Yu Y, Chen C, Zhao X, Zhu K, Yan Y (2018) Four-Terminal all-perovskite tandem solar cells achieving power conversion efficiencies exceeding 23\%. ACS Energy Lett 3:305-306. https://doi.org/10.1021/acsenergylett.7b01287

56. Moot T, Werner J, Eperon GE, Zhu K, Berry JJ, McGehee MD, Luther JM (2020) Choose your own adventure: fabrication of monolithic all-perovskite tandem photovoltaics. Adv Mater 2003312:1-22. https://doi.org/10.1002/adma.202003312

Publisher's Note Springer Nature remains neutral with regard to jurisdictional claims in published maps and institutional affiliations. 